\title{
A 22-year-old woman with right lumpy jaw syndrome and fistula
}

\author{
F Valour, $^{1,2,3}$ C Chidiac, $^{1,2,3}$ T Ferry, $^{1,2,3}$ on behalf of the Lyon Bone and Joint \\ Infection Study Group
}

${ }^{1}$ Service de Maladies Infectieuses et Tropicales, Hôpital de la Croix-Rousse, Hospices Civils de Lyon, Lyon, France

${ }^{2}$ Université Claude Bernard Lyon 1, Lyon, France ${ }^{3}$ Centre International de Recherche en Infectiologie (CIRI), Inserm U1111, CNRS UMR5308, ENS de Lyon, UCBL1, Lyon, France

Correspondence to Dr T Ferry,

tristan.ferry@univ-lyon1.fr

Accepted 16 January 2015
CrossMark

To cite: Valour F, Chidiac $C$, Ferry T, et al. BMJ Case Rep Published online: [please include Day Month Year] doi:10.1136/bcr-2014206557

\section{DESCRIPTION}

A 22-year-old woman attended the infectious diseases consultation for a 2-week history of painless afebrile submaxillary tumefaction with continuous serous exudate (figure 1A). Oral examination revealed multiple carious teeth (figure 1B). Panoramic dental radiography disclosed multiple periapical tooth abscesses (figure 1C, arrows). CT scan highlighted signs of chronic osteomyelitis of the lower mandible (figure 1D, arrows). Although actinomycosis was not proven, a regimen of amoxicillin $(6 \mathrm{~g} /$ day $)$ and clindamycin $(1800 \mathrm{mg} /$ day $)$ was initiated, associated to dental avulsion, providing rapid improvement of symptoms.

Lumpy jaw syndrome is well known by veterinarians, as it is frequent in cattle, swine, horses and dogs. It consists of a large unilateral abscess that grows on the head and neck of the infected animal, following dental disease and mandibular osteomyelitis. In humans, this syndrome is particularly associated with poor dental hygiene, periodontal disease and periapical dental abscess. ${ }^{1}$ Lumpy jaw syndrome is mainly due to anaerobic polymicrobial infection, including Actinomyces spp (filamentous Gram-positive bacilli belonging to the human commensal flora). ${ }^{2}$ Lumpy jaw syndrome is the most frequent clinical form of actinomycosis and can be associated with fistula, as in the our case. Treatment of dental disease (mainly dental avulsion) is essential, and antimicrobial therapy with high-dose amoxicillin is the treatment of choice. Association of a companion such as clavulanate or clindamycin is controversial, but may help target copathogens. ${ }^{13}$ 


\section{Learning points}

- Lumpy jaw syndrome associates unilateral head and neck abscess, mandibular osteomyelitis and dental infection.

- Actinomyces spp are the main oropharyngeal commensals involved in lumpy jaw syndrome.

- Dental avulsion and high doses of amoxicillin are usually the treatment of choice.
Emmanuel Jouanneau, Timothée Jacquesson, Pierre Breton, Ali Mojallal, Fabien Boucher, Hristo Shipkov; Microbiologists - Frederic Laurent, François Vandenesch, Jean-Philippe Rasigade, Céline Dupieux; Nuclear Medicine - Isabelle Morelec, Marc Janier, Francesco Giammarile; PK/PD specialists - Michel Tod, Marie-Claude Gagnieu, Sylvain Goutelle; Clinical Research Assistant - Eugénie Mabrut.

Contributors FV wrote the case. FV, CC and TF performed the literature review and participated to the revision of the manuscript.

Competing interests None.

Patient consent Obtained.

Provenance and peer review Not commissioned; externally peer reviewed.

\section{REFERENCES}

1 Lerner PI. The lumpy jaw. Cervicofacial actinomycosis. Infect Dis Clin North Am 1988;2:203-20.

Ferry, Thomas Perpoint, André Boibieux, François Biron, Florence Ader, Julien Saison, Florent Valour, Fatiha Daoud, Johanna Lippman, Evelyne Braun, Marie-Paule Vallat, Patrick Miailhes, Christian Chidiac, Dominique Peyramond; Surgeons - Sébastien Lustig, Philippe Neyret, Olivier Reynaud, Caroline Debette, Adrien Peltier, Anthony Viste, Jean-Baptiste Bérard, Frédéric Dalat, Olivier Cantin, Romain Desmarchelier, Thibault Vermersch, Michel-Henry Fessy, Cédric Barrey, Francesco Signorelli,
2 Valour F, Sénéchal A, Dupieux C, et al. Actinomycosis: etiology, clinical features, diagnosis, treatment and management. Infect Drug Resist 2014:183-97.

3 Oostman 0, Smego RA. Cervicofacial actinomycosis: diagnosis and management. Curr Infect Dis Rep 2005;7:170-4.

Copyright 2015 BMJ Publishing Group. All rights reserved. For permission to reuse any of this content visit

http://group.bmj.com/group/rights-licensing/permissions.

BMJ Case Report Fellows may re-use this article for personal use and teaching without any further permission.

Become a Fellow of BMJ Case Reports today and you can:

- Submit as many cases as you like

- Enjoy fast sympathetic peer review and rapid publication of accepted articles

- Access all the published articles

- Re-use any of the published material for personal use and teaching without further permission

For information on Institutional Fellowships contact consortiasales@bmjgroup.com

Visit casereports.bmj.com for more articles like this and to become a Fellow 